\title{
Analisis Pengaruh Kredit Ketahanan Pangan dan Energi (KKP-E) Terhadap Pendapatan Petani Ternak di Kabupaten Wonogiri
}

\author{
Eko Budi Utomo
}

\begin{abstract}
ABSTRAK
Penelitaan ini bertujuan untuk menganalisis pengaruh pemberian Kredit Ketahanan Pangan dan Energi (KKP-E) terhadap pendapatan petani ternak di Kabupaten Wonogiri. Metode dasar penelitian adalah metode analisis deskriptif dan pelaksanaannya dengan metode survey. Penelitian dilakukan di Kabupaten Wonogiri. Pengambilan sampel dengan metode simple random sampling. Hasil penelitian menunjukkan bahwa hubungan faktor-faktor dengan pendapatan peternak dinyatakan dalam model fungsi regresi linier berganda yaitu: $\mathrm{Y}=15178510.19+3713035.14 \mathrm{X}_{1}+362495.26 \mathrm{X}_{2}+169794.77 \mathrm{X}_{3}+315220.14$ $\mathrm{X}_{4}-125964.84 \mathrm{X}_{5}-451.03 \mathrm{X}_{6}-151.90 \mathrm{X}_{7}+2183539.09 \mathrm{D}_{1}-2157838.42 \mathrm{D}_{2}+\mathrm{e}$. Hasil analisis regresi menunjukkan bahwa jumlah ternak, jumlah anggota keluarga, tingkat pendidikan, pengalaman berternak, umur peternak, biaya pakan, biaya obat, penggunaan kredit, dan penguasaan lahan secara bersama-sama berpengaruh nyata terhadap pendapatan petani ternak. Secara individu faktor jumlah ternak, pengalaman berternak, biaya pakan, biaya obat dan pengguaan kredit berpengaruh nyata terhadap pendapatan petani ternak, sedangkan jumlah anggota keluarga, tigkat pendidikan, umur peternak, dan penguasaan lahan tidak berpengaruh nyata terhadap pendapatan petani ternak.
\end{abstract}

Kata kunci: Pendapatan, KKP-E, Peternakan Sapi Potong.

\section{Culture \& Bargaining Power Influence on School and Working Participation of Child in East Java}

\begin{abstract}
This research aimed to analyze the effect of Credit Food and Energy (KKP-E) to income of the cattle fattening business in Wonogiri District. Basic method of research is descriptive analysis method and implementation of research conducted by survey method. This research will be conducted in Wonogiri District. Samplingtechnique was used multistage cluster random sampling method. The resultsshowed that relationship between the factors with cattle farmers's income can beexpressed in multiple linear regression models as follows: $Y=15178510.19+3713035.14 X_{1}+362495.26 X_{2}+169794.77 X_{3}+$ $315220.14 X_{4}-125964.84 X_{5}-451.03 X_{6}-151.90 X_{7}+2183539.09 D_{1}-2157838.42 D_{2}+$ e.The results of the regression analysis showed that number of livestock ownership, Breeding experience, Cost offeed, Cost of drugs and use of KKP-E have significant effect on cattle farmers' income, whereas the number of family members, Level of education, age of farmers and Land ownership factor did not significantly affect tocattle farmers' income.
\end{abstract}

Keywords: Income, KKP-E, Cattle breeding.

\section{PENDAHULUAN}

Pembangunan pertanian memiliki peran yang strategis dalam perekonomian nasional. Peran strategis pertanian tersebut digambarkan melalui kontribusi yang nyata pada penyediaan bahan pangan, bahan baku industri, pakan dan bioenergi, penyerap tenaga kerja, sumber devisa negara, sumber pendapatan, serta pelestarian lingkungan melalui praktek usahatani yang ramah lingkungan. Berbagai peran strategis pertanian yang dimaksud sejalan dengan tujuan pembangunan perekonomian nasional yaitu meningkatkan kesejahteraan masyarakat Indonesia, mempercepat pertumbuhan ekonomi, mengurangi kemiskinan, menyediakan lapangan kerja, serta memelihara keseimbangan sumberdaya alam dan lingkungan hidup (Kementrian Pertanian, 2014).

Sub sektor peternakan merupakan bagian integral dari sektor pertanian. Pembangunan sub sektor peternakan bertujuan untuk meningkatkan 
pendapatan dan taraf hidup peternak melalui usaha peningkatan produksi baik secara kualitas maupun kuantitas. Selain itu pembangunan sub sektor peternakan merupakan bagian pembangunan pertanian secara umum yang diarahkan untuk mengembangkan pertanian yang maju dan efisien.

Usaha peternakan sapi potong di Indonesia sebagian besar (90\%) merupakan usaha peternakan rakyat. Kegiatan usaha peternakan sapi potong yang diusahakan oleh masyarakat khususnya di daerah pedesaan memiliki kemampuan dan andil dalam pemenuhan kebutuhan masyarakat untuk berbagai lapisan. Nilai manfaat yang disumbangkan dalam kegiatan usaha ternak sapi potong ini cukup besar berupa protein hewani, tenaga kerja dan limbah asal ternak. Kegiatan usaha ternak sapi potong melibatkan banyak pihak seperti masyarakat, petani ternak, importir sapi bakalan, industri pakan ternak, lembaga keuangan, konsumen, ilmuwan dan tentunya pemerintah.

Permintaan akan daging sapi di Indonesia dari tahun ketahun semakin meningkat, hal tersebut selain dipengaruhi oleh peningkatan jumlah penduduk juga dipengaruhi oleh peningkatan pengetahuan penduduk itu sendiri terhadap pentingnya protein hewani, sehingga pola konsumsi juga berubah. Pada tahun 2015, tingkat konsumsi daging sapi diperkirakan 613.110 ton, sementara produksi hanya 419.140 ton (Kementerian Pertanian, 2015). Konsekuensinya untuk mengatasi kekurangan daging sapi di Indonesia harus impor. Pada tahun 2010 impor daging sapi Indonesia adalah sebesar 90.506 ton atau setara dengan nilai US\$ 289,506 juta naik menjadi 246.509 ton pada tahun 2014 atau setara dengan nilai US\$ 681,229 juta (Kementerian Pertanian, 2015). Jika tidak ada perubahan teknologi secara signifikan dalam proses produksi daging sapi dalam negeri serta tidak adanya peningkatan populasi sapi yang berarti, maka kesenjangan antara produksi daging sapi dalam negeri dengan jumlah permintaan akan semakin melebar, sehingga berdampak pada volume impor yang semakin besar (Hadi, et.al., 1999).

Impor daging sapi juga menyebabkan daya saing peternakan dalam negeri menjadi kurang bersaing karena harga daging impor lebih murah dan penampilannya lebih baik. Sedangkan di Indonesia, harga daging relatif mahal sebagai akibat dari belum efisiennya usaha peternakan dalam negeri, yang ditunjukan oleh tingginya biaya produksi dan biaya distribusi ternak dari daerah sentra produsen ke daerah konsumen. Kondisi demikian berdampak terhadap terhambatnya perkembangan peternakan dalam negeri yang masih bersifat tradisional dan diusahakan sebagai usaha sampingan.

Bagi petani umumnya modal identik dengan pembiayaan yang sangat sulit untuk ditanggulangi khususnya dalam mengembangkan usaha tani di pedesaan. Akses petani pada sumbersumber pembiayaan resmi masih sangat terbatas. Oleh karena itu modal menjadi faktor penghambat dalam mengelola pertanian.

Sementara itu, di kalangan petani kecil terdapat sumber-sumber permodalan non-formal yang mudah mereka akses karena prosedurnya sangat sederhana dan persyaratannya mudah dipenuhi petani karena hanya mengandalkan kepercayaan. Walaupun tingkat bunga yang dikenakan terhadap petani debitur sangat tinggi, petani kecil merasa lebih nyaman dengan memanfaatkan sumber-sumber modal non-formal.

Melihat permasalahan yang dihadapi petani dalam permodalan tersebut, maka pemerintah berupaya membantu meringankan beban petani dengan menetapkan berbagai skim pembiayaan bagi petani kecil yang lebih mudah diakses oleh petani kecil. Kebijakan ini diharapkan dapat memberikan dampak positif bagi perkembangan usahatani bagi petani kecil di Indonesia. Salah satu jenis kredit program untuk pembiayaan pertanian yang saat ini diluncurkan Kementerian Pertanian adalah Kredit Ketahanan Pangan dan Energi (KKP-E).

Salah satu bank yang menjadikan agribisnis sebagai salah satu sektor unggulan adalah Bank Rakyat Indonesia (BRI). Salah satu bentuk kontribusi BRI adalah dengan menerapkan kebijakan pembiayaan di sektor agribisnis (Aviliani, 2008). Salah satu program kredit yang digulirkan oleh BRI terkait program revitalisasi pertanian adalah Kredit Ketahanan Pangan dan Energi (KKP-E). KKP-E dapat diakses melalui Kantor Cabang BRI di seluruh wilayah Indonesia, dan salah satunya ada di Kabupaten Wonogiri.

Mayoritas penduduk di Kabupaten Wonogiri bekerja di sektor pertanian, utamanya tanaman pangan dan peternakan. Menurut data Sensus Pertanian Tahun 2013 jumlah rumah tangga pengelola sapi sebanyak 91.660 rumah tangga dengan populasi ternak sapi sebanyak 154.917 
ekor terdiri dari 43.337 ekor jantan dan 111.580 ekor betina. Sub sektor peternakan di Kabupaten Wonogiri sangat potensial untuk dikembangkan, terutama untuk meningkatkan pendapatan petani. Cara yang dapat ditempuh untuk meningkatkan produksi dan pendapatan petani adalah dengan meningkatkan akses permodalan petani yang salah satunya dengan KKP-E.

Berdasarkan dengan latar belakang yang telah diuraikan di atas, maka dapat dirangkum tujuan penelitian, antara lain: (1) Untuk mengetahui biaya dan pendapatan usaha penggemukan sapi potong di Kabupeten Wonogiri. (2) Untuk mengetahui pengaruh pemberian Kredit Ketahanan Pangan dan Energi (KKP-E) terhadap pendapatan usaha penggemukan sapi potong di Kabupaten Wonogiri.

\section{Program Kredit Ketahanan Pangan dan Energi (KKP-E)}

Kredit Ketahanan Pangan dan Energi (KKP-E) adalah kredit investasi/modal kerja yang diberikan dalam rangka mendukung pelaksanaan Program Ketahanan Pangan dan Program Pengembangan Tanaman Baku Bahan Bakar Nabati (Kementerian Pertanian, 2014). KKP-E ditujukan untuk membantu permodalan petani dan peternak dengan suku bunga bersubsidi sehingga mereka dapat menerapkan teknologi rekomendasi budidaya. Sumber dana KKP-E berasal dari Bank Pelaksana, meliputi 22 Bank yaitu 8 Bank Umum: Bank BRI, Mandiri, BNI, Bukopin, CIMB Niaga, Agroniaga, BCA, dan BII serta 14 Bank Pembangunan Daerah (BPD) yaitu: BPD Sumatera Utara, Sumatera Barat, Sumatera Selatan, Jawa Barat, Jawa Tengah, D.I. Yogyakarta, Jawa Timur, Bali, Sulawesi Selatan, Kalimantan Selatan, Papua, Riau, Nusa Tenggara Barat dan Jambi. Resiko KKP-E ditanggung sepenuhnya oleh Bank Pelaksana, peran pemerintah dalam hal ini antara lain menyediakan subsidi suku bunga dan risk sharing untuk komoditas padi, jagung dan kedelai. Keputusan akhir kredit ada pada bank mengingat resiko kredit sepenuhnya ditanggung bank.

Besarnya tingkat bunga kredit bank untuk KKP-E tebu adalah sebesar $12 \%$ dan KKP-E lainnya sebesar $13 \%$, sedangkan tingkat bunga kepada peserta KKP-E adalah sebesar 7,5\% untuk KKP-E tebu dan 5,5\% untuk KKP-E lainnya dengan subsidi bunga 4,5\% untuk KKP-E tebu dan 7,5\% untuk KKP-E lainnya.

Realisasi penyaluran KKPE secara nasional yang tercatat sampai tahun 2013 (secara komulatif) adalah sebesar Rp. 12.684,1 milyar dari plafon sebesar Rp. 41.982,0 milyar (Kementrian Pertanian, 2014). Besarnya KKP-E yang disalurkan oleh BRI Cabang Wonogiri dari Tahun 2012 hingga 2014 sebesar Rp. 9,634 milyar untuk komoditas peternakan usaha penggemukan sapi.

Prosedur penyaluran KKP-E dapat dilihat pada Gambar 1.

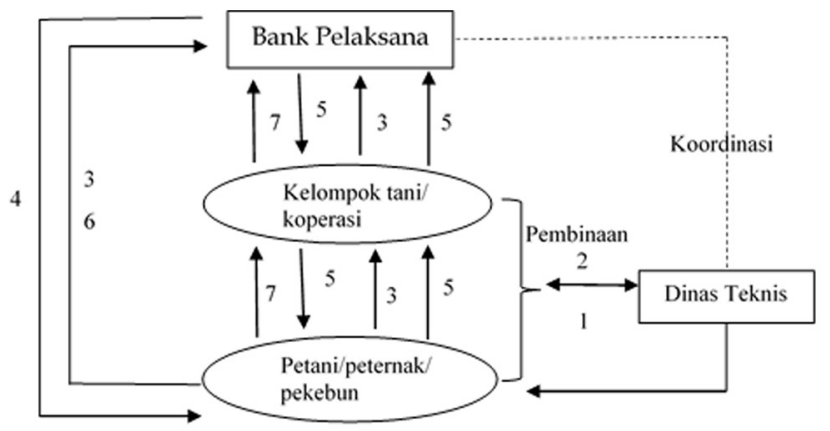

Gambar 1. Prosedur Penyaluran KKP-E kepada petani/ peternak/pekebun secara individu atau Kelompok Tani/ Koperasi secara langsung ke Bank

Keterangan :

1. Petani/peternak/pekebun yang langsung mengajukan kredit secara individu menyusun Rencana Kebutuhan Usaha (RKU) dan bagi kelompok tani menyusun menyusun RDKK (Rencana Definitif Kebutuhan Kelompok) dibantu oleh Petugas Dinas Teknis setempat.

2. Pejabat Dinas Teknis setempat mensahkan RKU atau RDKK dan Dinas mengeluarkan rekomendasi teknis.

3. Rencana Kebutuhan Usaha (RKU) petani/ peternak/pekebunan dan atau RDKK yang sudah disahkan diajukan langsung ke Bank Pelaksana.

4. Bank pelaksana meneliti kelengkapan dokumen usulan kredit, dan apabila dinilai layak dan memenuhi syarat, kemudian petani/peternak menandatangani akad kredit dengan cabang Bank Pelaksana dan menyalurkan kredit ke petani/ peternak.

5. Jika petani mengajukan kredit melalui Kelompok Tani maka RDKK diajukan ke bank pelaksana, jika memenuhi syarat kelompok tani menandatangi akad kredit dan KKP-E akan disalurkan kepada petani anggota kelompok.

6. Petani/peternak/pekebun yang secara individu langsung mengembalikan kredit kepada Bank pelaksana sesuai jadwal, dan bila melalui kelompok tani anggota mengembalikan kepada kelompok tani; 
7. Kelompok tani mengembalikan KKP-E langsung kepada Bank Pelaksana sesuai jadwal yang disepakati dalam akad kredit.

\section{Hipotesis Penelitian}

Bertitik tolak pada kenyataan bahwa petani hidup dalam keadaan miskin, keterlibatan mereka pada hutang dan persoalan tersulit dalam ekonomi pertanian adalah persoalan pembiayaan maka petani memerlukan kredit murah. Banyaknya kredit yang sekarang ada di kalangan petani membuat petani memiliki berbagai alternatif pilihan dalam mengatasi kekurangan pembiayaan namun tidak banyak kredit yang benar-benar berpihak pada kepentingan petani secara luas. Hanya kredit resmi pemerintah yang memiliki keunggulan dalam segi keberpihakannya pada kepentingan petani kecil. Oleh karenanya Kredit Ketahanan Pangan dan Energi (KKP-E) sebagai kredit resmi mempunyai peran penting membantu petani dalam penyediaan modal bagi pengelolaan usahatani.

Tersedianya kemudahan bagi petani terhadap akses perkreditan, keputusan usahatani yang tepat, dan persepsi petani yang benar terhadap Kredit Ketahanan Pangan dan Energi (KKP-E), diharapkan dapat meningkatkan pendapatan dan kesejahteraan petani.

Berdasarkan pendapatan yang ada dianalisis pendapatan petani ternak yang menggunakan KKP-E dan pendapatan petani ternak yang tidak menggunakan KKP-E sehingga didapatkan pengaruh KKP-E terhadap peningkatan pendapatan petani. Hipotesis dalam penelitan ini adalah:

1. Diduga usaha peternakan sapi potong yang diusahakan di Kabupaten Wonogiri mampu meningkatkan pendapatan peternak.

2. Diduga Kredit Ketahanan Pangan dan Energi yang diterima peternak akan berpengaruh positif terhadap pendapatan peternak.

\section{METODE PENELITIAN}

Metode yang digunakan dalam penelitian ini adalah metode deskripsi analisis yaitu penelitian yang didasarkan pada pemecahan masalah-masalah aktual yang ada pada masa sekarang. Data yang dikumpulkan mula-mula disusun, dijelaskan dan kemudian dianalisis.

Metode penentuan daerah penelitian dilakukan secara sengaja (purposive). Kabupaten Wonogiri dipilih sebagai lokasi penelitian karena kelompok tani ternak yang mengakses KKP-E cukup banyak dari tahun 2012 sampai dengan 2014 sebanyak 32 kelompok dan 11 peternak, dengan jumlah kredit yang cukup tinggi.

Teknik penetapan sampel menggunakan metode Simple Random Sampling, yaitu pengambilan contoh acak sederhana, setiap peternak mempunyai kesempatan yang sama untuk dipilih, peternak yang mengakses Program KKP-E dan tidak mengakses program KKP-E setelah sampel dipilih secara acak, sehingga terpilih jumlah sampel sebanyak 60 orang yang terdiri dari 30 orang peternak yang mengakses program KKP-E dan 30 orang peternak yang tidak mengakses program KKP-E.

Untuk pengumpulan data digunakan tiga macam teknik yaitu: Observasi, teknik ini dilakukan dengan mengadakan pengamatan langsung terhadap obyek yang akan diteliti sehingga didapatkan gambaran yang jelas mengenai daerah yang akan diteliti dan wawancara, teknik ini digunakan untuk mendapatkan data primer melalui wawancara langsung dengan responden berdasarkan daftar pertanyaan yang telah dipersiapkan terlebih dahulu serta pencatatan, teknik ini digunakan untuk mengumpulkan data primer dan sekunder, yaitu dengan mencatat hasil wawancara dengan responden dan data yang ada pada instansi pemerintah atau lembaga yang terkait dengan penelitian ini.

Untuk mengetahui pendapatan usahatani ternak penggemukan sapi menggunakan rumus :

$\begin{aligned} \mathrm{PdU} & =\mathrm{PrU}-\mathrm{BU} \\ & =(\mathrm{HxY})-\mathrm{BE}\end{aligned}$

Keterangan

$\mathrm{PdU}=$ Pendapatan usahatani ternak yang/ tidak memanfaatkan kredit KKP-E (Rp)

$\mathrm{PrU}=$ Penerimaan usahatani ternak yang/ tidak memanfaatkan kredit KKP-E (Rp)

$\mathrm{BU}=$ Biaya usahatani ternak yang/tidak memanfaatkan kredit KKP-E (Rp)

$\mathrm{H}=$ Harga produksi dari usahatani ternak $(\mathrm{Rp})$

$\mathrm{Y}=$ Hasil produksi dari usahatani ternak (ekor)

$\mathrm{BE}=$ Biaya eksplisit dari usaha usahatani ternak (Rp)

Guna mengetahui pengaruh program KKP-E terhadap pendapatan petani ternak, 
Tabel 1. Karakteristik Sampel Peternak Pengguna KKP-E dan Peternak Bukan Pengguna KKP-E di Kabupaten Wonogiri

\begin{tabular}{|c|c|c|c|}
\hline No & Uraian & KKP-E & $\begin{array}{l}\text { Bukan } \\
\text { KKP-E }\end{array}$ \\
\hline 1 & Jumlah peternak responden (orang) & 30 & 30 \\
\hline 2 & Rata-rata umur peternak (tahun) & 47,8 & 47,9 \\
\hline \multirow[t]{5}{*}{3} & Pendidikan peternak & & \\
\hline & a. Tidak tamat SD - SD (orang) & 8 & 6 \\
\hline & b. SLTP (orang) & 6 & 7 \\
\hline & c. SLTA (orang) & 11 & 16 \\
\hline & d. Perguruan Tinggi (orang) & 5 & 1 \\
\hline 4 & $\begin{array}{l}\text { Rata-rata jumlah anggota keluarga } \\
\text { peternak (orang) }\end{array}$ & 4 & 4 \\
\hline 5 & $\begin{array}{l}\text { Rata-rata pengalaman berternak } \\
\text { (tahun) }\end{array}$ & 17 & 15 \\
\hline 6 & $\begin{array}{l}\text { Rata-rata jumlah ternak yang } \\
\text { dipelihara (ekor) }\end{array}$ & 5 & 2 \\
\hline
\end{tabular}

Sumber: Analisis Data Primer

merupakan analisis terhadap pendapatan petani ternak pengguna KKP-E dan peternak bukan pengguna KKP-E. Analisis ini menggunakan metode analisis regresi linier berganda, dengan model penduga sebagai berikut :

$\mathrm{Y}=\alpha+\beta_{1} \mathrm{X}_{1}+\beta_{2} \mathrm{X}_{2}+\beta_{3} \mathrm{X}_{3}+\beta_{4} \mathrm{X}_{4}+\beta_{5} \mathrm{X}_{5}+\beta_{6} \mathrm{X}_{6}+$ $\beta_{7} X_{7}+\beta_{8} D_{1}+\beta_{9} D_{2}+e$

dimana :

$\alpha \quad=$ konstanta,

$\beta_{1}, \beta_{2}, \beta_{3}, \beta_{4}, \beta_{5}, \beta_{6}, \beta_{7}, \beta_{8}, \beta_{9}=$ koefisienvariabel,

$\mathrm{Y} \quad=$ jumlah pendapatan peternak sapi potong

$(\mathrm{Rp})$

$\mathrm{X}_{1}=$ jumlak ternak (ekor)

$\mathrm{X}_{2}=$ jumlah anggota keluarga (orang)

$\mathrm{X}_{3} \quad=$ tingkat pendidikan (tahun)

$\mathrm{X}_{4} \quad=$ pengalaman berternak (tahun)

$\mathrm{X}_{5} \quad=$ umur peternak (tahun)

$\mathrm{X}_{6} \quad=$ biaya pakan (Rp/ekor/hari)

$\mathrm{X}_{7} \quad=$ biaya obat (Rp/ekor / periode)

$\mathrm{D}_{1}=$ Penggunaankredit $(\mathrm{D}=1$, pengguna

KKP-E, D = 0, bukanpengguna KKP-E).

$\mathrm{D} \quad=$ Penguasaan lahan pertanian $(\mathrm{D}=1$, Punya lahan pertanian/sewa, $\mathrm{D}=0$, tidak punya lahan pertanian) e $\quad=$ Standar error, yaitu pengaruh variabel lain yang tidak masuk ke dalam model, tetapi ikut mempengaruhi Tingkat Pendapatan Peternak Sapi Potong di Kabupaten Wonogiri.

\section{HASIL DAN PEMBAHASAN}

Karakteristik Peternak Sampel

Karakteristik peternak sampel merupakan gambaran umum mengenai latar belakang dan keadaan yang berkaitan dengan usaha penggemukan sapi potong peternak pengguna KKP-E BRI dan peternak bukan pengguna KKP-E BRI di Kabupaten Wonogiri. Peternak sebagai pengelola, merupakan faktor penentu dalam mencapai keberhasilan usaha. Karakteristik sosial peternak yang dianalisis meliputi umur, tingkat pendidikan, pengalaman beternak, jumlah keluarga dan jumlah ternak yang dipelihara.

Rata-rata umur peternak pengguna KKP-E dan bukan pengguna KKP-E tergolong dalam usia produktif yaitu rata-rata usia 47,7 tahun bagi peternak pengguna KKP-E dan 47,9 tahun bagi peternak bukan pengguna KKP-E. Tingkat pendidikan yang ditamatkan peternak bervariasi. Peternak pengguna KKP-E dan Peternak bukan pengguna KKP-E paling banyak menamatkan 
Tabel 2. Rata-rata Penerimaan dan Pendapatan Usaha Ternak Sapi Pengguna KKP-E dan Peternak Bukan Pengguna KKP-E di Kabupaten Wonogiri

\begin{tabular}{lcr}
\hline \multicolumn{1}{c}{ Uraian } & KKP-E (rupiah) & $\begin{array}{c}\text { Bukan KKP-E } \\
\text { (rupiah) }\end{array}$ \\
\hline Penerimaan (penjualan ternak) & $119.660 .000,-$ & $56.743 .333,-$ \\
\hline Biaya & $109.832 .000,-$ & $53.339 .667,-$ \\
\hline Pendapatan & $9.828 .000,-$ & $3.403 .667,-$ \\
\hline Sumber: Analisis Data Primer & & \\
\hline
\end{tabular}

pendidikannya pada tingkat SLTA. Rata-rata jumlah anggota keluarga Peternak pengguna KKP-E dan Peternak bukan pengguna KKP-E sama yaitu empat orang. Rata-rata pengalaman Peternak pengguna KKP-E dan peternak bukan pengguna KKP-E tidak jauh berbeda. Peternak pengguna KKP-E memiliki rata-rata pengalaman dalam berternak selama 17 tahun, sedangkan Peternak bukan pengguna KKP-E memiliki ratarata pengalaman dalam berternak selama 15 tahun. Jumlah rata-rata ternak yang dipelihara Peternak pengguna KKP-E dan Peternak bukan pengguna KKP-E terpaut 3 ekor. Rata-rata ternak yang dipelihara Peternak pengguna KKP-E adalah 5 ekor dan rata-rata ternak yang dipelihara Peternak bukan pengguna KKP-E adalah 2 ekor.

\section{Penerimaan dan Pendapatan Berternak Sapi}

Rata-rata pendapatan peternak pengguna KKP-E dan peternak bukan pengguna KKP-E dapat dilihat pada Tabel 2.

Rata-rata pendapatan usaha ternak sapi peternak pengguna KKP-E adalah Rp. 9.828.000,sedangkan rata-rata pendapatan usaha ternak sapi peternak bukan pengguna KKP-E adalah Rp. 3.403.667,-. Pendapatan peternak pengguna KKP-E lebih tinggi dikarenakan rata-rata penerimaan yang lebih tinggi dan ternak yang dipelihara lebih banyak. Ternak yang dipelihara peternak pengguna KKP-E lebih banyak karena adanya tambahan modal yang di akses dari kredit KKP-E. Tingkat pendapatan yang diperoleh peternak dari hasil usaha peternakan sapi potong memberikan gambaran terhadap kondisi produksi, dimana semakin tinggi tingkat pendapatan peternak akan memberikan gambaran bahwa usaha peternakannya berhasil dan ini akan berdampak pada kesejahteraan peternak.

Faktor-faktor yang Mempengaruhi Pendapatan Peternak Sapi Potong di Kabupaten Wonogiri

Dalam mengestimasi pengaruh program KKP-E terhadap pendapatan petani ternak sapi potong di Kabupaten Wonogiri menggunakan bantuan program software Eviews 9.0. Estimasi menggunakan metode Ordinary Least Square (OLS) dilakukan dengan cara menguji setiap parameter dengan menghitung nilai $t$ statistik dan nilai F statistik. Setelah data tersebut diolah dengan menggunakan software Eviews 9.0, maka diperoleh persamaan umum sebagai berikut:

$Y=15178510.19+3713035.14 X_{1}+362495.26$ $\mathrm{X}_{2}+169794.77 \mathrm{X}_{3}+315220.14 \mathrm{X}_{4}-125964.84$ $X_{5}-451.03 X_{6}-151.90 X_{7}+2183539.09 D_{1}-$ $2157838.42 \mathrm{D}_{2}+\mathrm{e}$.

dimana :

$\mathrm{Y} \quad=$ jumlah pendapatan peternak sapi potong (Rp/periode)

$\mathrm{X}_{1}=$ jumlak ternak (ekor)

$\mathrm{X}_{2} \quad$ = jumlah anggota keluarga (orang)

$\mathrm{X}_{3} \quad=$ tingkat pendidikan (tahun)

$\mathrm{X}_{4} \quad=$ pengalaman berternak (tahun)

$\mathrm{X}_{5} \quad=$ umur peternak (tahun)

$\mathrm{X}_{6} \quad=$ biaya pakan (Rp/ekor/hari)

$\mathrm{X}_{7} \quad$ = biaya obat (Rp/ekor/ periode)

$\mathrm{D}_{1} \quad=$ Penggunaan kredit $(\mathrm{D}=1$, pengguna KKP-E, $\mathrm{D}=0$, bukan pengguna KKP-E).

$\mathrm{D}_{2}=$ Penguasaan lahan pertanian $(\mathrm{D}=1$, Punya lahan pertanian/sewa, $\mathrm{D}=0$, tidak punya 
Tabel 3. Hasil Analisis Regresi Pengaruh Beberapa Faktor terhadap Pendapatan Petani Ternak Sapi Potong di Kabupaten Wonogiri

\begin{tabular}{|c|c|c|c|c|}
\hline No & Variabel & $\begin{array}{c}\text { Koefisien } \\
\text { Regresi } \\
\end{array}$ & t-hitung & $\begin{array}{l}\text { Probabilitas } \\
\text { Signifikansi }\end{array}$ \\
\hline 1. & Jumlah Ternak $\left(\mathrm{X}_{1}\right)$ & 3713035 & 16.87243 & $0.0000^{* * *}$ \\
\hline 2. & Jumlah Anggota Keluarga $\left(X_{2}\right)$ & 362495.3 & 0.602410 & $0.5496^{\mathrm{ns}}$ \\
\hline 3. & Tingkat Pendidikan $\left(X_{3}\right)$ & 169794.8 & 1.001839 & $0.3212^{\mathrm{ns}}$ \\
\hline 4. & Pengalaman Berternak $\left(X_{4}\right)$ & 315220.1 & 2.917799 & $0.0053^{\star \star *}$ \\
\hline 5. & Umur Peternak $\left(X_{5}\right)$ & -125964.8 & -1.365095 & $0.1783^{\text {ns }}$ \\
\hline 6. & Biaya Pakan $\left(\mathrm{X}_{6}\right)$ & -451.0363 & -3.478970 & $0.0011^{\star \star \star}$ \\
\hline 7. & Biaya Obat $\left(X_{7}\right)$ & -151.9007 & -2.182840 & $0.0338^{* *}$ \\
\hline 8. & Penggunaan Kredit $\left(\mathrm{D}_{1}\right)$ & 2183539. & 2.381983 & $0.0211^{\star *}$ \\
\hline \multirow[t]{4}{*}{9.} & Penguasaan Lahan $\left(\mathrm{D}_{2}\right)$ & -2157838. & -1.508949 & $0.1376^{\text {ns }}$ \\
\hline & Adjusted R-Square & 0.927151 & & \\
\hline & F-Statistik & 84.43309 & & \\
\hline & F-Sig & 0.000000 & & \\
\hline
\end{tabular}

Sumber: Analisis Data Primer

Keterangan: $\left.{ }^{* *}\right)$ : berpengaruh nyata pada tingkat kepercayaan $95 \%$

$* * *)$ : berpengaruh nyata pada tingkat kepercayaan $99 \%$

ns): tidak berpengaruh nyata pada tingkat kepercayaan $95 \%$ dan $99 \%$

lahan pertanian)

e $\quad=$ Standar error, yaitu pengaruh variabel lain yang tidak masuk ke dalam model, tetapi ikut mempengaruhi Tingkat Pendapatan Peternak Sapi Potong di Kabupaten Wonogiri.

$\mathrm{R}^{2}$ ditujukan untuk menghitung seberapa besar variasi dari variabel dependen dapat dijelaskan oleh variasi dari variabel independen. Nilai statistik koefisien determinasi yang telah disesuaikan (adjusted R-squared) yang diperoleh dari hasil estimasi adalah sebesar 0.927. Ini berarti bahwa 92.7 persen variasi variabel Pendapatan Petani Ternak dapat dijelaskan oleh variasi dari variabel independen yang dimaksudkan dalam model, sedangkan sisanya sebesar 7.3 persen dijelaskan oleh variasi dari variabel lain yang tidak termasuk dalam model.

Hasil estimasi dengan metode OLS diperoleh nilai F-hitung sebesar 84.431 dengan probabilitas signifikansi sebesar 0,000, lebih besar daripada nilai F-tabel 2.12 pada tingkat $\alpha 5 \%$. Hal tersebut menunjukkan bahwa semua variabel independen secara serentak berpengaruh secara signifikan terhadap variabel dependen pada tinngkat $\alpha 5 \%$ atau derajat keyakinan 95\%.

\section{Pengaruh Masing-masing Faktor Terhadap} Pendapatan Peternak (Uji t)

Jumlah kepemilikan ternak ternyata secara statistik sangat signifikan dan berpengaruh posistif terhadap variabel pendapatan petani ternak. Artinya apabila jumlah kepemilikan ternak meningkat maka pendapatan petani ternak juga meningkat, begitu pula sebaliknya jika jumlah kepemilikan ternak menurun maka pendapatan petani ternak juga akan menurun. Hal ini sesuai dengan pendapat Setiani, dkk (2013) yang menyatakan bahwa semakin banyak ternak sapi potong yang dimiliki peternak akan mempertinggi pendapatan yang diterima. Ternak sapi merupakan salah satu komponen penting bagi penyedia daging dimasyarakat. Banyaknya permintaan daging akan mempengaruhi harga ternak sapi dipasaran. Naiknya harga ternak sapi akan meningkatkan pendapatan petani ternak dan semakin banyak jumlah sapi yang dimiliki petani semakin banyak juga pendapatan yang diterima petani ternak. Krisna dan Mansur (2006) menyatakan bahwa semakin besar skala usaha yang dijalankan dan dimiliki maka akan semakin besar penerimaan yang akan diterima dan dapat juga menekan biaya produksi yang dikeluarkan.

Parameter jumlah anggota keluarga ternyata secara statistik tidak signifikan mempengaruhi variabel pendapatan petani ternak. Hal ini selaras dengan pendapat Riadi, dkk (2014) yang menyatakan bahwa, mestinya makin banyak anggota keluarga makin banyak pekerja yang merawat ternak, tetapi pada kenyataanya tenaga kerja yang bertanggung jawab terhadap ternaknya hanya bapak dan ibu petani sedangkan anak tidak 
dibebani untuk ikut merawat ternaknya.

Berdasarkan banyaknya jumlah anggota keluarga diharapkan banyak pula anggota keluarga yang aktif pada usaha peternakan sapi. Namun pada kenyataannya, rata-rata dalam satu rumah tangga petani hanya ada dua orang saja yang aktif dalam usaha peternakan sapi, yaitu pasangan suami-istri saja. Sebagian dari anggota keluarga lebih memilih untuk bekerja di luar usaha tani seperti di pabrik atau sebagai buruh bangunan, dan sebagian lagi masih sekolah.

Parametertingkatpendidikanternyatasecara statistik tidak signifikan mempengaruhi variabel pendapatan petani ternak. Pendidikan formal tidak terlalu berpengaruh terhadap pendapatan usaha tani. Sesuai dengan pendapat Riadi, dkk (2014) yang manyatakan berternak sapi potong tidak memerlukan ilmu dari pendidikan formal tetapi dari pengalaman. Umumnya tingkat pendidikan akan berpengaruh pada tingkat penyerapan informasi dan inovasi. Namun demikian, informasi dan inovasi yang dibutuhkan oleh peternak tidak didapatkan dari pendidikan formal. Informasi dan inovasi dalam hal peternakan justru lebih sering didapatkan peternak dari pendidikan non-formal seperti kursus dan penyuluhan.

Parameter pengalaman berternak ternyata secara statistik signifikan dan berpengaruh posistif terhadap variabel pendapatan petani ternak. Artinya apabila pengalaman berternak Bertambah maka pendapatan petani ternak juga meningkat. Semakin lama beternak pengalaman yang diperoleh semakin banyak, sehingga pengelolaan usaha peternakan semakin baik. Dengan pengalaman beternak yang cukup lama memberikan indikasi bahwa pengetahuan dan ketrampilan peternak terhadap manajemen pemeliharaan ternak mempunyai kemampuan yang lebih baik. Menurut Abidin dan Simanjuntak (1997), faktor penghambat berkembangnya peternakan pada suatu daerah tersebut dapat berasal dari faktor-faktor topografi, iklim, keadaaan sosial, tersedianya bahan-bahan makanan rerumputan atau penguat, disamping itu faktor pengalaman yang dimiliki peternak masyarakat sangat menentukan pula perkembangan peternakan didaerah itu.

Parameter umur peternak ternyata secara statistik tidak signifikan mempengaruhi variabel pendapatan petani ternak. Faktor umur biasanya lebih diidentikkan dengan produktivitas kerja, dan jika seseorang masih tergolong usia produktif ada kecenderungan produktivitasnya juga tinggi. Chamdi (2003) mengemukakan, semakin muda usia peternak (usia produktif 20-45 tahun) umumnya rasa keingintahuan terhadap sesuatu semakin tinggi dan minat untuk mengadopsi terhadap introduksi teknologi semakin tinggi. Tarmidi (1992) menyatakan, orang muda memiliki kemampuan fisik yang kuat juga mempunyai kemampuan berfikir lebih tajam serta lebih mudah menerima hal-hal baru serta mampu mengembangkan usahanya dan ada kemungkinan menambah pengetahuan serta metode budidaya di bidang usaha ternak sapi potong.

Parameter biaya pakan ternyata secara statistik signifikan dan berpengaruh negatif terhadap variabel pendapatan petani ternak. Artinya apabila biaya pakan meningkat maka pendapatan petani ternak akan turun. Hal ini sesuai dengan pendapat Ginting (2013) yang menyatakan harga pakan konsentrat bepengaruh negatif terhadap pendapatan di mana semakin tinggi harga pakan konsentrat maka akan menyebabkan semakin tingginya biaya yang dikeluarkan untuk pembelian konsentrat, dengan demikian akan menurunkan pendapatan dari usaha penggemukan sapi. Kenaikan kompenen bahan pakan akan menyebabkan pembengkaan biaya produksi untuk pemeliharaan ternak, sehingga akan mengurangi pandapatan yang akan diterima peternak.

Pada usaha pemeliharaan sapi potong (keREMan) dalam batas waktu tertentu peningkatan kualitas dan jumlah pakan yang diberikan akan dapat meningkatkan pendapatan, karena sejalan akan menyebabkan capaian tambahan bobot badan harian yang lebih tinggi pula. Namun pada sisi yang lain menurut Basuno, dkk., (1995) dan Bambang Winarso, (2004) apabila waktu pemeliharaan dilakukan semakin panjang (lama) maka biaya pakan juga cenderung akan semakin meningkat, sehingga pada akhirnya malah akan mengurangi pendapatan yang diperoleh karena biaya pakan adalah komponen terbesar dari total biaya.

Parameter biaya obat ternyata secara statistik signifikan dan berpengaruh negatif terhadap variabel pendapatan petani ternak. Artinya apabila Biaya obat meningkat maka pendapatan petani ternak akan turun. Pemberian obat yang dimaksud pada analisis ini terdiri dari (obat cacing dan vitamin), dengan tujuan untuk meningkatkan tingkat kesehatan ternak, melindungi dari penyakit serta memberikan dorongan untuk meningkatkan 
hasil produksi melalui penggunaan vitamin. Bilamana komponen harga obat dan vitamin naik akan mempengaruhi pengeluaran untuk biaya kesehatan ternak, sehingga akan mempengaruhi pendapatan peternak yang akan diterima.

Parameter penggunaan kredit ternyata secara statistik signifikan dan berpengaruh posistif terhadap variabel pendapatan petani ternak. Artinya apabila peternak menggunakan Kredit KKP-E maka pendapatan petani ternak akan meningkat, bila tidak menggunakan kredit KKP-E tidak akan menambah pendapatan. Hal ini sesuai pendapat Dahri, dkk., (2015) bahwa dari paket kredit yang diperoleh peternak, umumnya mereka dapat membeli 2-4 ekor sapi dewasa per orang. Dengan demikian jumlah ternak yang dipelihara peternak meningkat. Bagi peternak sapi potong, dengan tambahan modal tersebut, maka peternak dapat menggemukkan sapi lebih banyak dan selanjutnya menjual lebih banyak. Dengan demikian asumsinya keuntungan pun meningkat. Kredit KKPE dapat menambah sapi 2-4 ekor, maka pendapatan pun meningkat Rp. 1,5 juta/bulan.

Hasil pendugaan dampak KKP-E terhadap pendapatan peternak ditampilkan pada Tabel 2 . Pendapatan petani ternak yang dimaksud dalam studi ini adalah penerimaan (revenue) dikurangi dengan biaya yang dibayarkan (biaya eksplisit). Hasil analisis pendapatan menunjukkan bahwa pengguna KKP-E pendapatannya lebih besar di banding bukan pengguna KKP-E. Selaras dengan hasil penelitian Setiawan (2005) yang menyatakan semakin tinggi kredit yang diterima petani, maka laba usaha taninya juga akan semakin tinggi.

Parameter penguasaan lahan ternyata secara statistik tidak signifikan mempengaruhi variabel pendapatan petani ternak.

\section{KESIMPULAN DAN SARAN}

Berdasarkan hasil penelitian pada usaha peternakan sapi peternak pengguna KKP-E dan peternak bukan pengguna KKP-E di Kabupaten Wonogiri dapat ditarik kesimpulan bahwa hasil analisis variabel modal penggunaan kredit berpengaruh nyata dan mempunyai hubungan yang positif terhadap pendapatan petani ternak di Kabupaten Wonogiri. Artinya apabila peternak menggunakan Kredit KKP-E maka pendapatan petani ternak akan meningkat, bila tidak menggunakan kredit KKP-E tidak akan menambah pendapatan.
Berdasarkan hasil penelitian dan kesimpulan, dapat diketahui bahwa KKP-E memberikan manfaat dan pengaruh terhadap pendapatan petani ternak, namun demikian, belum banyak petani ternak yang mengetahui adanya KKP-E sehingga tidak banyak petani yang mengakses program KKP-E. Hal yang dapat disarankan adalah adanya sosialisasi mengenai KKP-E oleh pemerintah melalui petugas kecamatan kepada semua kelompok tani sehingga seluruh petani anggota kelompok tani menjadi paham mengenai program pemerintah dalam hal kredit atau bantuan permodalan utamanya KKP-E beserta pengaruh dan manfaatnya dalam pengembangan usahatani.

\section{DAFTAR PUSTAKA}

Abidin, A dan Simanjuntak, D. 1997. Ternak Sapi Potong. Direktorat Jenderal Peternakan, Jakarta

Aliman. 2000. Modul Ekonometrika Terapan. PAU Studi Ekonomi UGM, Yogyakarta.

Ashari. 2009. Peran Perbankan Nasional dalam Pembiayaan Sektor Pertanian di Indonesia. Forum Penelitian Agro Ekonomi. 27 (1): 13-27. Pusat Analisis Sosial Ekonomi dan Kebijakan Pertanian.

Asri, M. Dan M. Hidayat, 1984. Linier Programming. Edisi Kedua BPFE, Jogyakarta.

Aviliani. 2008. Peran BRI dalam Membangun Ekonomi Berbasis Agribisnis yang Tangguh dan Kompetitif. Agrimedia. 13 (1): 7-12.

Basuno, E., Sabrani. M., dan Sunandar, N. 1995. Diskripsi dan analisis produksi usaha sapi perah di Pujon, Malang, Jawa Timur. Seminar Nasional Sains dan Teknologi Peternakan. Balitnak, Bogor.

Chamdi, AN. 2003. Kajian Profil Sosial Ekonomi Usaha Kambing di Kecamatan Kradenan Kabupaten Grobogan. Prosiding Seminar Nasional Teknologi Peternakan dan Veteriner. Puslitbang Peternakan Departemen Pertanian, Bogor. 
Dahri, Parulian Hutagaol, Hermanto Siregar, Pantjar Simatupang, 2015. Dampak Kredit Program KKPE Dalam Pengembangan Usaha Ternak Sapi Di Tingkat Peternak Di Jawa Tengah. Jurnal Manajemen dan Agribisnis. 12 (2): 115-125. Manajemen dan Bisnis, IPB, Bogor.

Ginting, A.b., 2013. Faktor-Faktor Yang Mempengaruhi Pendapatan Usahatani Padi Dan Usaha Penggemukan Sapi Potong (Studi Kasus : Kecamatan Purwodadi Kabupaten Grobogan). Jurnal Penelitian Bidang Ilmu Pertanian. 11(3): 106-118. Bidang Ilmu Pertanian, Kopertis Wilayah I.

Gujarati, Damodar, 1999. Ekonometrika Dasar, Terjemahan Sumarno Zain, Cetakan 6 Gelora. Aksara Pratama, Jakarta.

Hadi, P.U., H.P. Saliem dan Nyak Ilham, 1999. Pengkajian Konsumsi Daging dan Kebutuhan Impor Daging Sapi dalam Sudaryanto et. al. (eds) Analisis dan Perspektif Kebijaksanaan pembangunan Pertanian Pasca Krisis Ekonomi. Monograph Series No.20. PSE. Bogor.

Kementerian Pertanian, 2012. Pedoman Teknis Skim Kredit Ketahanan Pangan dan Energi (KKP-E). Direktorat Pembiayaan Pertanian Direktorat Jenderal Prasarana dan Sarana Pertanian, Kementerian Pertanian, Jakarta.

, 2014. Pedoman Teknis Skim Kredit Ketahanan Pangan dan Energi (KKP-E). Direktorat Pembiayaan Pertanian Direktorat Jenderal Prasarana dan Sarana Pertanian, Kementerian Pertanian, Jakarta.

2015. Outlook Komoditas Pertanian Sub Sektor Peternakan Daging Sapi. Pusat Data dan Sistem Informasi Pertanian, Sekretariat Njenderal, Kementerian Pertanian, Jakarta.

Krisna, R. dan E. Manshur, 2006. Tingkat Pemilikan Sapi (Skala Usaha) Peternakan Dan Hubungannya Dengan Keuntungan
Usaha Tani Ternak Pada Kelompok Tani Ternak Sapi Perah Di Desa Tajur Halang Bogor. Jurnal Penyuluhan Pertanian. 1(1): 61-64. Jurusan Penyuluhan Peternakan STPP Bogor.

Parakkasi, A. 1985. Ilmu Nutrisi dan Makanan Ternak Ruminansia. UI Press, Jakarta.

Rahim, A dan Hastuti, DRW. 2007. Ekonomi Pertanian. Penebar Swadaya, Jakarta.

Riadi, S., Syarifuddin Nur, Krismiwati Muatip. 2014. Faktor-Faktor Yang Berpengaruh Terhadap Pendapatan Peternak Sapi Di Kabupaten Banyumas. Jurnal Ilmiah Peternakan. 1(2): 313-318. Fakultas Peternakan, UNSOED.

Setiani, H.E., Syarifuddin Nur, Oentoeng Edy Djatmiko. 2013. Analisis Perbandingan Pendapatan Peternak Kelompok Penerima Bantuan Pemerintah Dan Kelompok Mandiri Pada Kelompok Ternak Sapi Potong Di Kabupaten Purbalingga. Jurnal Ilmiah Peternakan. 1(2): 639 - 646. Fakultas Peternakan, UNSOED.

Siregar, A.P., 1984. Peranan Ternak dan Pakan Dalam Usahatani. Risalah Lokakarya Teknologi dan Dampak Penelitian Pola Tanam dan Usahatani, Bogor.

Soekartawi, A. Soehardjo, J.L. Dillon, J.B. Hardaker, 1986. Ilmu Usahatani dan Penelitian untuk Pengembangan Petani Kecil. UI - Press, Jakarta.

Soetriono. Suwandari, A. Rijanto.2006. Pengantar Ilmu Pertanian. Bayumedia Publishing, Malang.

Suratiyah, K. 2015. Ilmu Usahatani. Edisi Revisi. Penebar Swadaya, Jakarta.

Susanti, I., Arief Daryanto, Muladno, 2012. Kebijakan Pemerintah Dalam Pembiayaan Usaha Pembibitan Ternak Sapi. Jurnal Manajemen dan Agribisnis. 9(3): 137-145. Manajemen dan Bisnis, IPB. 
Tarmidi, Lepi T.(1992). Ekonomi Pembangunan. Pusat Antar Universitas, Studi Ekonomi, Universitas Indonesia.

Winarso, 2004. Prospek Pengembangan Usaha Ternak Sapi Potong di Kalimantan Timur. Working Paper. Pusat Penelitian dan Pengembangan Sosial Ekonomi Peternakan, Bogor. 